\title{
Enhanced nitrogen removal in constructed wetlands: Effects of dissolved oxygen and step-feeding
}

\author{
Fengmin $\mathrm{Li}^{\mathrm{a}, *}$, Lun Lu ${ }^{\mathrm{a}}$, Xiang Zheng ${ }^{\mathrm{b}}$, Huu Hao $\mathrm{Ngo}^{\mathrm{c}}$, Shuang Liang ${ }^{\mathrm{d}}$, Wenshan Guo ${ }^{\mathrm{c}}$, Xiuwen Zhang ${ }^{\mathrm{a}}$ \\ a Key Laboratory of Marine Environmental Science and Ecology, Ministry of Education, Ocean University of China, Qingdao 266100, China \\ ${ }^{\mathrm{b}}$ School of Environment and Natural Resources, Renmin University of China, Beijing 100872, China \\ 'School of Civil and Environmental Engineering, University of Technology Sydney, Broadway, NSW 2007, Australia \\ ${ }^{\mathrm{d}}$ Shandong Key Laboratory of Water Pollution Control and Resource Reuse, School of Environmental Science E Engineering, Shandong University, Jinan 250100, China
}

\section{H I G H L I G H T S}

- Artificial aeration can significantly improve oxygenation for nitrification in HSFCWs.

- Step-feeding was found to be crucial for high TN removal in HSFCWs.

- Denitrification was enhanced due to high $\mathrm{C} / \mathrm{N}$ ratio introduced by step-feeding.

- Combination of artificial aeration and step-feeding significantly enhanced TN removal.

\section{A R T I C L E I N F O}

\section{Article history:}

Received 30 April 2014

Received in revised form 30 June 2014

Accepted 1 July 2014

Available online 9 July 2014

\section{Keywords:}

Constructed wetland

Dissolved oxygen

Step-feeding

Nitrification

Denitrification

\begin{abstract}
A B S T R A C T
Four horizontal subsurface flow constructed wetlands (HSFCWs), named HSFCW1 (three-stage, without step-feeding), HSFCW2 (three-stage, with step-feeding), HSFCW3 (five-stage, without step-feeding) and HSFCW4 (five-stage, with step-feeding) were designed to investigate the effects of dissolved oxygen (DO) and step-feeding on nitrogen removal. High removal of 90.9\% COD, 99.1\% ammonium nitrogen and $88.1 \%$ total nitrogen (TN) were obtained simultaneously in HSFCW4 compared with HSFCW1-3. The excellent TN removal of HSFCW4 was due to artificial aeration provided sufficient DO for nitrification and the favorable anoxic environment created for denitrification. Step-feeding was a crucial factor because it provided sufficient carbon source (high COD: nitrate ratio of 14.3) for the denitrification process. Microbial activities and microbial abundance in HSFCW4 was found to be influenced by DO distribution and step-feeding, and thus improve TN removal. These results suggest that artificial aeration combined with step-feeding could achieve high nitrogen removal in HSFCWs.
\end{abstract}

(c) 2014 Elsevier Ltd. All rights reserved.

\section{Introduction}

Excessive discharge of nitrogen to water bodies is an important contributing factor to eutrophication, which is one of the main environmental problems worldwide. Eutrophication can result in serious degradation of aquatic ecosystems and impair water quality for drinking, industry, agriculture, recreation, or other purposes (Conley et al., 2009; Kadlec and Wallace, 2008). Biological treatment technologies such as activated sludge processes and membrane bioreactor have been widely used to treat nitrogen polluted wastewaters for water purification and water reuse. However, these approaches often demand operation costs and energy consumption, and thus are still limited in rural areas (Judd, 2008;

\footnotetext{
* Corresponding author.

E-mail address: lifengmin@ouc.edu.cn (F. Li).
}

Stare et al., 2007). Hence, alternative methods are needed for full control of waste nitrogen.

Compared to conventional energy-intensive treatment technologies, constructed wetlands (CWs) are efficient and environment-friendly treatment technology with low cost of construction, operation and maintenance, and are preferred for treating widely distributed rural domestic wastewaters (Vymazal, 2011). A recent review on nitrogen removal in CWs noted that classical nitrogen removal route, known as nitrification-denitrification, is still the major nitrogen removal route in subsurface flow CWs when compared with other novel routes (i.e., partial nitrification-denitrification, anaerobic ammonium oxidation, completely autotrophic nitrite removal over nitrate) (Saeed and Sun, 2012). Consequently, either nitrification or denitrification process suffocation causes low total nitrogen (TN) removal efficiency. The TN treatment performance in CWs can be influenced by various 
environmental parameters and operating conditions, of which dissolved oxygen (DO) and chemical oxygen demand to nitrate concentration $(\mathrm{COD} / \mathrm{N})$ ratio are crucial in nitrogen transformation (Ding et al., 2012; Saeed et al., 2012). Nitrifying bacteria competing with organics for limited DO is a key problem in conventional biological nitrogen removal (Kadlec and Wallace, 2008; Tanner and Kadlec, 2003). Therefore, the nitrification process represents the main limiting step for nitrogen removal in subsurface flow CWs because of low oxygen availability (Kuschk et al., 2003). In addition, as the typical configurations (i.e., unaerated surface flow and subsurface flow) often suffer from the deficiency of electron donor during the biological denitrification, removals of TN normally remain at approximately $50 \%$ in most cases with nitrogen loading rate in the range of $0.6-2 \mathrm{~g} \mathrm{~N} \mathrm{~m}^{-2} \mathrm{~d}^{-1}$ (Hu et al., 2012a; Warneke et al., 2011).

Artificial aeration has been proven to be the most effective alternative to guarantee sufficient oxygen supply, which can facilitate nitrification (Fan et al., 2013b; Hu et al., 2012a; OuelletPlamondon et al., 2006). Denitrification subsequently is extremely important for complete TN elimination when nitrification is guaranteed. Furthermore, external carbon addition (Lu et al., 2009), internal carbon addition or organic media (Saeed et al., 2012), recirculation (Ayaz et al., 2012) are the common options in practice to efficiently utilize carbon source to promote denitrification. HSFCWs. Until recently, some studies was carried to investigate step-feeding in improving TN removal in vertical flow CWs (Hu et al., 2012b; Fan et al., 2013a), nevertheless, the effect of stepfeeding on TN removal in HSFCWs are remained unclear, and the combination of aeration and step-feeding on nitrogen removal process has rarely been reported anywhere. Therefore, it is quite necessary to qualify and evaluate the combined effect of aeration and step-feeding in HSFCWs on nitrogen removal.

In this study, novel HSFCWs with DO control strategies (i.e., artificial aeration, buffer stage, and artificial anoxic treatment) and step-feeding were developed and evaluated for simultaneously enhanced removal of organics and nitrogen. The design allows the pollutants being treated under different conditions such as spatial aerobic, anoxic, and anaerobic in one constructed wetland system. The combined effects of DO control strategies and step-feeding on nitrogen removal were comprehensively investigated by analyzing different forms of nitrogen (ammonia, nitrite, nitrate and TN). Microbial abundance and microbial activities in different stages are also investigated in details.

\section{Methods}

\subsection{System description and operation}

This experiment was conducted based on previous research (Li et al., 2014) with modifications and improvements. Four laboratory-scale HSFCW systems were constructed with polyvinyl chloride board and set up indoors, which could be divided into two groups, namely Group 1: two three-stage HSFCWs (HSFCW1 and HSFCW2) with a total length of $1.25 \mathrm{~m}$, width of $0.2 \mathrm{~m}$, and depth of $0.3 \mathrm{~m}$, and Group 2: two five-stage HSFCWs (HSFCW3 and HSFCW4) with the same width and depth but different length of $2.1 \mathrm{~m}$ (Fig. 1a and b). Different DO control strategies were employed to create proper DO distribution (aerobic condition and anoxic condition) in the three-stage HSFCWs and five-stage HSFCWs. For all HSFCWs, in order to provide sufficient DO to create aerobic condition for nitrification, forced air was provided by an aeration system, which consisted of an air compressor and aeration tube. Artificial anoxic treatment was performed by sealing the compartment with plastic sheets to cut off oxygen diffusion; buffer stage was the conventional compartment without artificial aeration or artificial anoxic treatment. Buffer stage followed by two stages with artificial anoxic treatment in five-stage HSFCWs was expected to achieve more efficient anoxic condition for denitrification. In order to provide carbon source for dinitrification, step-feeding was employed. Each group has one HSFCW without step-feeding (HSFCW1: three stage, without step-feeding; HSFCW3: five stage, without stepfeeding), while the other with step-feeding (HSFCW2: three stage, with step-feeding; HSFCW4: five stage, with step-feeding). All HSFCWs were filled with $5 \mathrm{~cm}$ deep gravel (3-5 cm in diameter) followed by $15 \mathrm{~cm}$ of cinder (1-3 cm in diameter) and $5 \mathrm{~cm}$ of sandy soil (60\% sand, $0.5-4 \mathrm{~mm}$ in diameter). Plants were not involved in all wetland systems.

To obtain stable treatment performance, all four HSFCWs has been operated for about a month prior to the experiments. Influent feed and aeration were in continuous mode during the operation. For HSFCW2 and HSFCW4 with step-feeding, main stream and side stream accounted for $80 \%$ and $20 \%$ of the total influent, respectively. Hydraulic loading was maintained at $15 \mathrm{~L} \mathrm{~d}^{-1}$ for each wetland system. Nominal hydraulic retention time (HRT) was calculated according to Kadlec and Wallace (2008). The HRTs for the three-stage HSFCWs and five-stage HSFCWs were 5 days and 8.4 days, respectively.

\subsection{Wastewater}

The experiments were conducted using a synthetic wastewater to avoid fluctuation in feed concentration. The synthetic wastewater was composed of $400 \mathrm{mg} \mathrm{L}^{-1}$ glucose, $20 \mathrm{mg} \mathrm{L}^{-1}$ peptone, $80 \mathrm{mg} \mathrm{L}^{-1}\left(\mathrm{NH}_{4}\right)_{2} \mathrm{SO}_{4}, 50 \mathrm{mg} \mathrm{L}^{-1} \mathrm{NaHCO}_{3}$, and $10 \mathrm{mg} \mathrm{L}^{-1} \mathrm{CaCl}_{2}$. The wastewater was stored in a $200 \mathrm{~L}$ tank before being dosed into the wetland system. The chemical characteristics of the influent are illustrated in Table 1.

\subsection{Microbial abundance and activities}

The total number of bacteria was determined by using the general bacterial stain DAPI (4', 6-diamidino-2-phenylindole) method (Porter, 1980). Five grams of media were added to a $200 \mathrm{ml}$ conical flask containing $95 \mathrm{ml} 0.85 \%$ saline, and the flask was shaken at $200 \mathrm{r} \mathrm{min}^{-1}$ for $1 \mathrm{~h}$. A $10 \mathrm{~mL}$ extract was added with $0.2 \mathrm{ml}$ formalin for fixing purpose, then stained with DAPI, filtered by $0.22 \mu \mathrm{m}$ filter paper (Whatman No. 2) at low pressure, and counted using an epifluorescence microscope. Each sample was counted from 10 visions, and the number of microorganisms counted was converted to the number of microorganisms per liter in the extract, which indicated the microbial abundance of wetland media.

Microbial activity within the matrix in each stage was assessed by using fluorescein diacetate (FDA) method at the end of the experiment (Green et al., 2006). Three grams of media were firstly added into a $50 \mathrm{ml}$ conical flask containing sterilized phosphate buffer solution ( $\mathrm{pH}=7.6$ ), following by adding $1 \mathrm{ml}$ FDA solution $(6.0 \mu \mathrm{M})$. Then, the prepared flask was incubated in an orbital incubator at $30^{\circ} \mathrm{C}$ for $3 \mathrm{~h}$. Afterwards, $2 \mathrm{ml}$ of acetone was added and the suspension was swirled to terminate the FDA hydrolysis. The mixture was then transferred to $50 \mathrm{ml}$ centrifuge tubes and the suspension was centrifuged at $8000 \mathrm{r} \mathrm{min}^{-1}$ for $3 \mathrm{~min}$ in a refrigerated centrifuge. Finally, the supernatant was filtered through a Whatman No. 2 filter paper. The filtrate was transferred to a colorimeter tube and measured using a spectrophotometer at $490 \mathrm{~nm}$. Microbial activity was represented as $\mu$ g-fluorescein diacetate/ g-matrix per hour. Three repetitions of each sampling point were measured and three samples without matrix served as control.

\subsection{Sampling and chemical analysis}

Samples from influent, effluent, and each stage were collected once a week and analyzed within $24 \mathrm{~h}$ after collection for COD, 

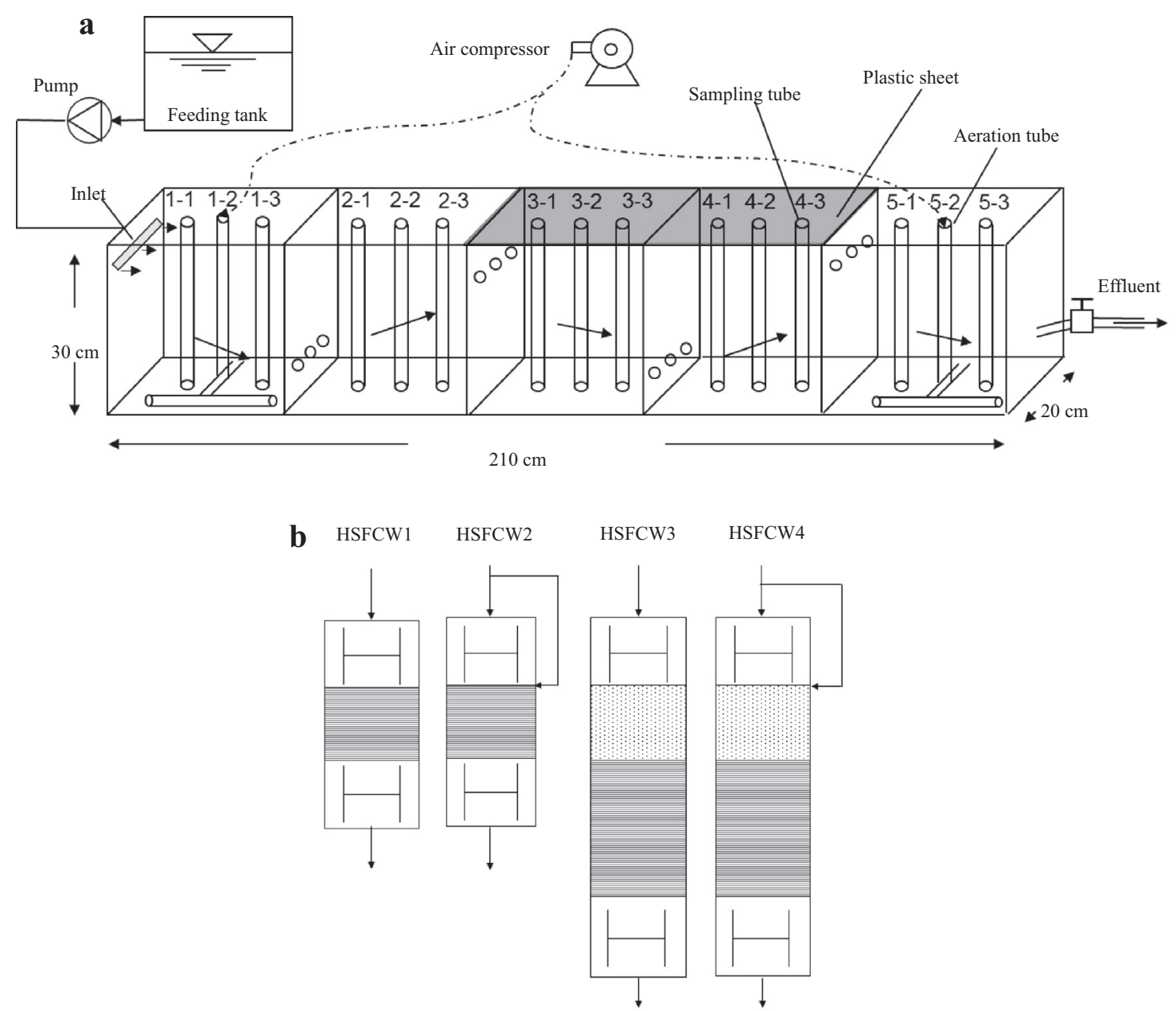

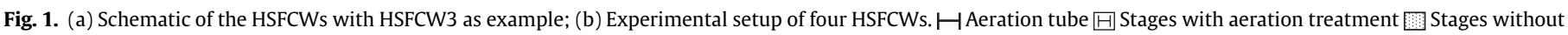
aeration treatment or anoxic treatment

Table 1

Influent and effluent wastewater characteristics and pollutant removal performances in wetland systems (means \pm standard deviation).

\begin{tabular}{|c|c|c|c|c|c|c|c|c|c|}
\hline \multirow[t]{2}{*}{ Parameter $\left(\mathrm{mg} \mathrm{L}^{-1}\right)$} & \multirow[t]{2}{*}{ Influent } & \multicolumn{2}{|l|}{ HSFCW1 } & \multicolumn{2}{|l|}{ HSFCW2 } & \multicolumn{2}{|l|}{ HSFCW3 } & \multicolumn{2}{|l|}{ HSFCW4 } \\
\hline & & Effluent & Removal (\%) & Effluent & Removal (\%) & Effluent & Removal (\%) & Effluent concentration & Removal (\%) \\
\hline $\mathrm{pH}^{\alpha}$ & $7.2 \pm 0.4$ & $7.2 \pm 0.3$ & NA & $7.1 \pm 0.4$ & NA & $7.3 \pm 0.5$ & NA & $7.3 \pm 0.4$ & NA \\
\hline DO & $1.3 \pm 0.4$ & $3.4 \pm 0.4$ & NA & $3.5 \pm 0.4$ & NA & $3.5 \pm 0.4$ & NA & $3.4 \pm 0.4$ & NA \\
\hline COD & $257.4 \pm 12.0$ & $32.9 \pm 3.3$ & $87.2 \pm 1.9$ & $82.9 \pm 12.5$ & $67.8 \pm 6.7$ & $43.2 \pm 4.4$ & $83.2 \pm 2.9$ & $23.3 \pm 6.0$ & $90.9 \pm 3.3$ \\
\hline $\mathrm{NH}_{4}^{+}-\mathrm{N}$ & $20.1 \pm 2.4$ & $0.2 \pm 0.4$ & $99.0 \pm 2.2$ & $1.3 \pm 1.0$ & $93.5 \pm 10.4$ & $0.2 \pm 0.3$ & $98.9 \pm 1.5$ & $0.2 \pm 0.3$ & $99.1 \pm 1.9$ \\
\hline $\mathrm{NO}_{2}^{-}-\mathrm{N}$ & $0.02 \pm 0.02$ & $0.15 \pm 0.24$ & NA & $0.46 \pm 0.48$ & NA & $0.31 \pm 0.40$ & NA & $0.27 \pm 0.27$ & NA \\
\hline $\mathrm{NO}_{3}^{-}-\mathrm{N}$ & $0.09 \pm 0.08$ & $9.36 \pm 1.05$ & NA & $6.83 \pm 3.08$ & NA & $9.02 \pm 4.63$ & NA & $2.13 \pm 2.67$ & NA \\
\hline TN & $21.8 \pm 1.8$ & $9.7 \pm 1.9$ & $55.5 \pm 7.4$ & $8.6 \pm 1.2$ & $60.6 \pm 8.2$ & $9.5 \pm 1.6$ & $56.4 \pm 7.3$ & $2.5 \pm 0.9$ & $88.1 \pm 4.8$ \\
\hline
\end{tabular}

NA: not applicable.

${ }^{\alpha} \mathrm{pH}$ is unitless.

$\mathrm{NH}_{4}^{+}-\mathrm{N}, \mathrm{NO}_{3}^{-}-\mathrm{N}, \mathrm{NO}_{2}^{-}-\mathrm{N}, \mathrm{TN}, \mathrm{pH}$, and $\mathrm{DO}$ (as illustrated in Fig. $1 \mathrm{~b}, \mathrm{a}$ total of 11 and 17 samples were included in the three-stage and five-stage HSFCWs, respectively). For each sample, DO and $\mathrm{pH}$ were measured in situ using a pH meter (AB15, Fisher Scientific, USA) and a DO tester (Oxi 3205SET3, WTW, Germany), respectively. $\mathrm{COD}, \mathrm{NH}_{4}^{+}-\mathrm{N}, \mathrm{NO}_{3}^{-}-\mathrm{N}, \mathrm{NO}_{2}^{-}-\mathrm{N}$ were analyzed using a Hach $\mathrm{DR} / 2400$ (USA) spectrophotometer by the colorimetric method according to its standard operating procedures. TN was analyzed by alkaline potassium persulfate digestion-UV spectro photometric method as described in Standard Method for the Examination of Water and Wastewater Editorial Board (2002).

\subsection{Statistical analysis}

All experimental data were expressed as means of triplicates with standard deviation. Data analysis was performed using two-way ANOVA and Type III sum of squares with the SPSS 18.0 software (SPSS Inc., Chicago, USA) to investigate the difference in treatment performance between two different types of HSFCWs (three-stage and five-stage HSFCWs with different DO control strategies), with or without step-feeding, and the interaction between two types of HSFCWs and step-feeding treatment. The software was used for all statistical analyses, including analysis 
of variance, Bartlett's and Levine's tests for homogeneity of variance and normality. Differences between individual means were identified using Tukey HSD-procedure at the 5\% significance level. Tamhane's T2 was selected for that equal variance between groups was not assumed.

\section{Results and discussion}

\subsection{Overall performance}

With the characteristics of influent identified, the difference in treatment performance of examined HSFCWs could be revealed from the varied effluent quality. Table 1 gives the measured results of influent, effluent, pollutant removal profiles (expressed as concentration), and removal efficacy (expressed as percentages) for each HSFCW system, while Table 2 illustrates the effect of two types of HSFCWs, step-feeding and the interaction between them on treatment performance. All the system demonstrated satisfactory removal of $\mathrm{COD}$ and $\mathrm{NH}_{4}^{+}-\mathrm{N}$, and $\mathrm{COD}$ and $\mathrm{NH}_{4}^{+}-\mathrm{N}$ removal were depended strongly on the types of HSFCWs, step-feeding and the interaction between them, except $\mathrm{NH}_{4}^{+}-\mathrm{N}$ did not depend on the interaction between types of HSFCWs and step-feeding. Average COD removal efficiencies were all above $80 \%$ except for HSFCW2 (67.8\%), indicating that high COD removal could be guaranteed with artificial aeration (Fan et al., 2013a; Hu et al., 2012b). Moreover, the artificial aeration also promoted $\mathrm{NH}_{4}^{+}-\mathrm{N}$ removal. $\mathrm{NH}_{4}^{+}-\mathrm{N}$ removal averaged $99.0 \%, 93.5 \%, 98.9 \%$, and $99.1 \%$ for HSFCWs 1-4, respectively, reflecting that the nitrification was not the limiting step for effective TN removal in this study. These results indicated that artificial aeration was an effective strategy for HSFCWs to enhance COD and $\mathrm{NH}_{4}^{+}-\mathrm{N}$ removal, which was consistent with the findings of Ouellet-Plamondon et al. (2006) that the COD and $\mathrm{NH}_{4}^{+}-\mathrm{N}$ removal efficiencies in the aerated wetland reactors were significantly higher than those without aeration. As shown by the significant interactions in the ANOVA (Table 2), TN removal was also strongly depended on different types of HSFCWs, with or without step-feeding, and the interaction between the two types of HSFCWs and step-feeding treatment. TN removal was limited by insufficient denitrification in HSFCW1 and HSFCW3, as only $55.5 \%$ and $56.4 \%$ TN removal were observed respectively. However, with step-feeding, TN removal increased up to $60.6 \%$ in HSFCW2 compared with HSFCW1 and HSFCW3. The best TN removal performance was achieved in HSFCW4 with an average of $88.1 \%$, which was a substantial improvement from the general TN removal (23-59\%) reported in other previous studies (Brix, 1994; Sun et al., 2005; Warneke et al., 2011). The results stated that the combination of DO control strategies and step-feeding was effective for enhancing the performance of HSFCWs in terms of TN removal, which deserved further discussion.

\subsection{Effect of aeration and step-feeding on COD removal}

The aerobic and anoxic conditions in the wetland systems were distinguished by DO profiles. Fig. 2a shows the spatial profile of DO

\section{Table 2}

F-Values and significance of a two-way ANOVA of treatment performance HSFCWs with two different types of HSFCWs (three-stage and five-stage HSFCWs with different DO control strategies), feeding (with or without step-feeding), and the interaction between two types of HSFCWs and step-feeding treatment.

\begin{tabular}{lccc} 
& Types & Feeding & Types $\times$ feeding \\
\hline $\mathrm{COD}$ & $202.31^{* * *}$ & $1075.98^{* * *}$ & $546.72^{* * *}$ \\
$\mathrm{NH}_{4}^{+} \mathrm{N}$ & $38.65^{* *}$ & $38.41^{* * *}$ & 2.12 \\
$\mathrm{TN}$ & $267.31^{* * *}$ & $160.26^{* * *}$ & $140.37^{* * *}$ \\
\hline
\end{tabular}

\footnotetext{
** $P<0.01$.
}

${ }^{* * *} P<0.001$.
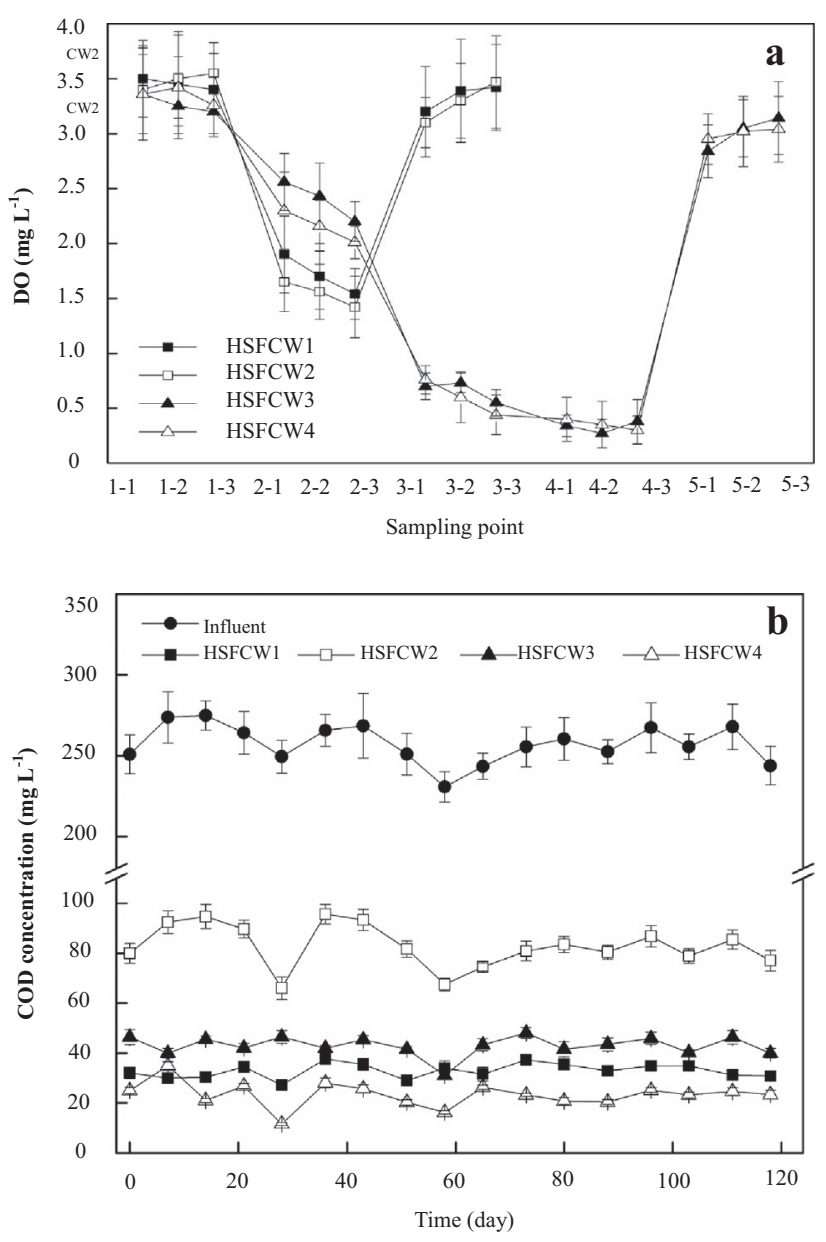

Fig. 2. (a) DO profiles for four HSFCWs along the flow, and (b) COD concentration of four HSFCWs. Error bars are standard deviations of the mean.

distribution along the flow direction in four HSFCWs. Different DO control strategies were applied, for example, artificial aeration and anoxic treatment in HSFCWs 1 and 2, and aerobic treatment, anoxic treatment, and buffer stage in HSFCWs 3 and 4. Significant DO distinction was observed, although the DO level along the flow direction in HSFCWs followed the same high-low-high tendency. With artificial aeration, the DO concentrations in the aerobic stages, in spite of various HSFCWs, were all above $3.0 \mathrm{mg} \mathrm{L}^{-1}$, which was significantly higher than $1.3 \mathrm{mg} \mathrm{L}^{-1} \mathrm{DO}$ of the influent $(p<0.01)$. However, in anoxic stage, the DO concentrations of HSFCWs 1 and 2 was considerably higher than those of HSFCWs 3 and 4. The reasons are that, compared with the three-stage HSFCWs, the five-stage systems had a buffer stage to further consume oxygen, as well as two-time anoxic treatment could achieve better anoxic condition within the matrix more strictly. As can be seen from Fig. 2b, the lowest DO concentrations for HSFCWs 3 and 4 were below $0.5 \mathrm{mg} \mathrm{L}^{-1}$, suggesting that the anoxic treatment were close to anaerobic condition (Fan et al., 2013b). DO concentrations in aerobic stages with supplementary aeration are between 3.0 and $3.5 \mathrm{mg} \mathrm{L}^{-1}$, which could meet the requirement for organics degradation and nitrification (Hu et al., 2012b). This favorable DO distribution well created alternating aerobicanoxic-aerobic environment within the HSFCWs 3 and 4, resulting in simultaneous removal of organics and nitrogen (Fan et al., 2013b).

The treatment efficiency of the constructed wetlands for organic removal is highly dependent on the oxygen concentration within the matrix in the bed and the wetland design (Vymazal and Kropfelova, 2009). Fig. 2b presents the influent and effluent COD 
concentrations for the four HSFCWs during the experiment. Although the influent exhibits fluctuation (ranging from $230.7 \mathrm{mg} \mathrm{L}^{-1}$ to $274.9 \mathrm{mg} \mathrm{L}^{-1}$ with a mean value of $257.4 \mathrm{mg} \mathrm{L}^{-1}$ ), each HSFCW maintains relatively stable effluent COD concentration. For HSFCW1 and HSFCW3 without step-feeding, the effluent COD averaged $43.2 \mathrm{mg} \mathrm{L}^{-1}$ and $32.9 \mathrm{mg} \mathrm{L}^{-1}$ (Table 1 ), respectively, indicating the effectiveness of aeration for elevating COD removal (Li et al., 2014). As mentioned previously (Section 3.1), the types of HSFCWs significantly influenced COD removal performance (Table 2). The COD removal of HSFCW1 was significantly lower than that of HSFCW3 (Table S1), which could be ascribed to the relatively shorter HRT in HSFCW1 (Section 2.1). As adoption of stepfeeding to a HSFCW with short HRT may be inappropriate in COD removal, high effluent COD concentration was detected in HSFCW2 during the experiment (Table 1 and Fig. 2b). This adverse effect of step-feeding on COD removal was also detected by Stefanakis et al. (2011), who compared the COD removal efficiency of pilot-scale HSFCWs with and without wastewater step-feeding. They found that COD removal in HSFCW with step-feeding was slightly lower than that in HSFCW without step-feeding with HRT up to 14 days. The best COD removal performance was obtained in HSFCW4 (mean value of $23.3 \mathrm{mg} \mathrm{L}^{-1}$ ), which was lower than the limit for Class IV water quality for surface water $\left(30 \mathrm{mg} \mathrm{L}^{-1}\right)$ regulated by GB3838-2002 (SEPA, 2007). On the contrary, step-feeding in HSFCW4 did not adversely affect COD removal (Table 1 and Fig. $2 \mathrm{~b}$ ) because of the longer HRT ( $8.4 \mathrm{~d})$ in HSFCW4.

\subsection{Combined effect of DO control and step-feeding on nitrogen removal}

Nitrogen profiles including TN removal of four systems at different sampling points from inlet to outlet are depicted in Fig. 3. Mean
$\mathrm{NH}_{4}^{+}-\mathrm{N}$ removal for HSFCWs 1-4 reached 99.0\%, 93.5\%, 98.9\%, and $99.1 \%$, respectively (Table 1 ), indicating that all wetland systems fulfilled nearly complete nitrification as a result of sufficient DO supplied by artificial aeration. Due to the competition for oxygen consumption between the degradation of organics (COD) and the oxidation of ammonia (Saeed and Sun, 2012), $\mathrm{NH}_{4}^{+}-\mathrm{N}$ still existed after the first aerobic stage but remained at an extremely low level after further oxidation in the second aerobic stage. Therefore, in practice, this operation strategy might increase cost to allow wastewater flowing through an aerobic condition to further remove $\mathrm{NH}_{4}^{+}-\mathrm{N}$ before discharge, and this step is particularly important for step-feeding wetland system (Hu et al., 2012b) or treating high-strength wastewater (Hu et al., 2012a; Saeed et al., 2012).

The DO remained at a high average of $1.42 \mathrm{mg} \mathrm{L}^{-1}$ (Fig. 2a) in HSFCW1, which was assumed to be responsible for $\mathrm{NO}_{x}{ }^{-}-\mathrm{N}$ accumulation after passing the aerobic stage (Fig. 3a) because the process of denitrification would occur primarily under low DO content and anoxic stages (i.e., $<0.3-0.5 \mathrm{mg} \mathrm{L}^{-1}$ ) (Fan et al., 2013b; Kadlec and Wallace, 2008). Nevertheless, compared with DO in HSFCW1, the DO in anoxic stages was as low as $0.27 \mathrm{mg} \mathrm{L}^{-1}$ in HSFCW3 (Fig. 2a), demonstrating that buffer stage and anoxic treatment successfully created the favorable anoxic environment for denitrification. TN removals in HSFCW1 and HSFCW3 were $55.5 \%$ and $56.4 \%$, respectively, which did not show any significant difference (Table S1), suggesting that full denitrification could not be achieved merely under anoxic condition (Saeed and Sun, 2012). $\mathrm{NO}_{x}{ }^{-}-\mathrm{N}$ accumulation started from stage 2 in HSFCW3, which revealed that denitrification was limited due to carbon deficiency. The stoichiometric requirement for denitrification was reported to be $3.75 \mathrm{~g} \mathrm{COD} \mathrm{g} \mathrm{N}^{-1}$ when acetate is used as a sole carbon source (Thauer et al., 1977). In this study, glucose was used as the main
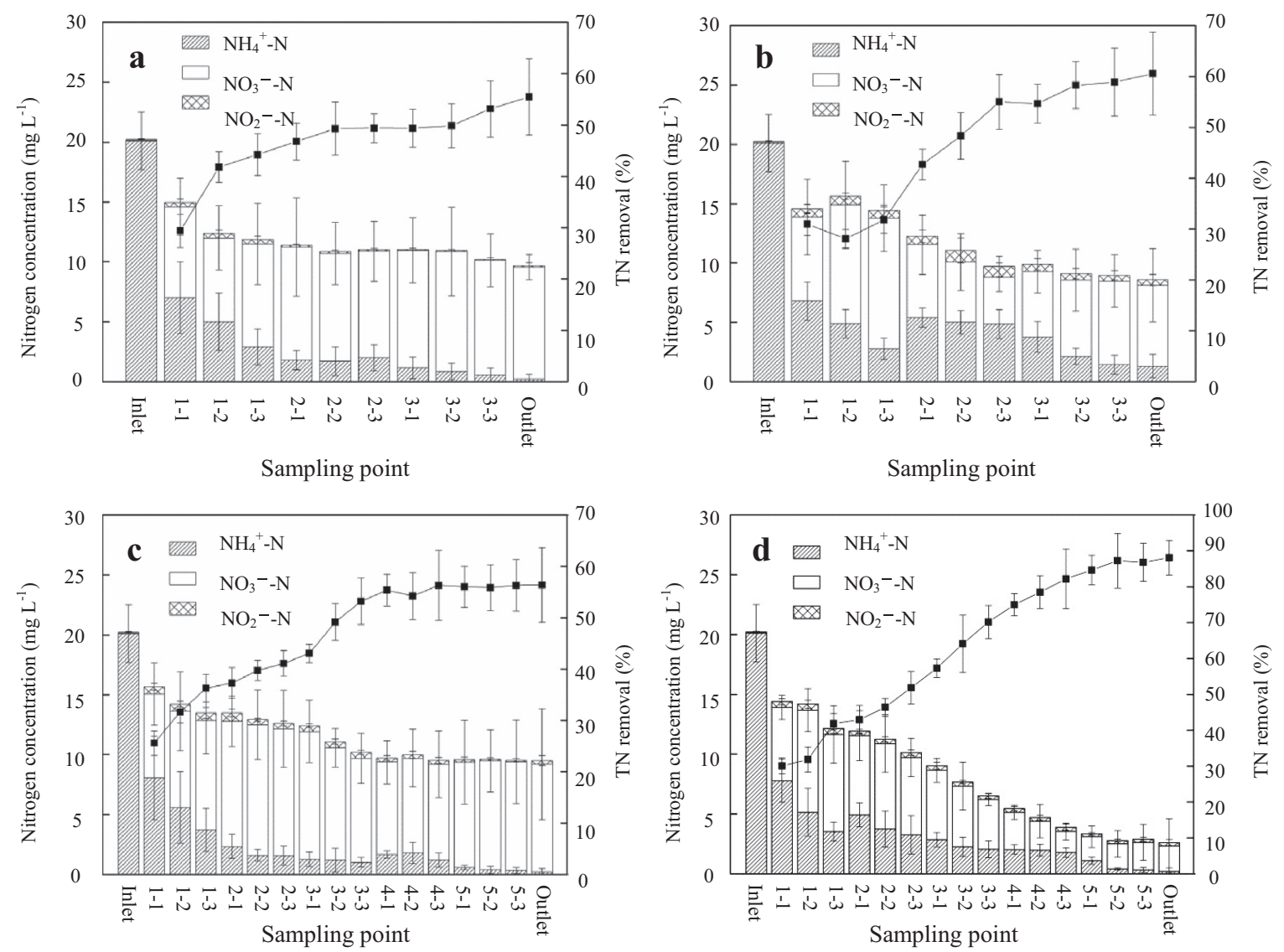

Fig. 3. Nitrogen profiles and TN removal in different HSFCWs: (a) HSFCW1; (b) HSFCW2; (c) HSFCW3; and (d) HSFCW4. Error bars are standard deviations of the mean. 
Table 3

Comparative evaluation of TN removal performance.

\begin{tabular}{|c|c|c|c|c|}
\hline System & Strategy & $\begin{array}{l}\text { Nitrogen removal } \\
\text { efficiency }\end{array}$ & Description of the study & Reference \\
\hline $\begin{array}{l}\text { Multi-stage horizontal subsurface } \\
\text { flow constructed wetland }\end{array}$ & $\begin{array}{l}\text { Artificial aeration }+ \text { anoxic } \\
\text { treatment }+ \text { step-feeding }\end{array}$ & $\begin{array}{l}99 \% \text { for } \mathrm{NH}_{4}^{+}-\mathrm{N} \\
88.1 \% \text { for } \mathrm{TN}\end{array}$ & $\begin{array}{l}\text { The effective spatial aerobic-anoxic-aerobic } \\
\text { environment facilitates organics and nitrogen } \\
\text { removal simultaneously. Carbon source introduced } \\
\text { by flow distribution promotes denitrification }\end{array}$ & This study \\
\hline Hybrid constructed wetland & $\begin{array}{l}\text { HFCW + VFCW, } \\
\text { Recirculation }\end{array}$ & $\begin{array}{l}98 \% \text { for } \mathrm{TKN} \\
79 \% \text { for } \mathrm{TN}\end{array}$ & $\begin{array}{l}\text { HFCW supports denitrification in addition to } \\
\text { removal of organic matter, whereas VFCW obtained } \\
\text { nitrification. } 33 \%, 100 \% \text {, and } 200 \% \text { recirculation ratio } \\
\text { was performed. Results show that a hybrid } \\
\text { constructed wetland system with recirculation is an } \\
\text { effective method to obtain low nitrogen } \\
\text { concentrations }\end{array}$ & $\begin{array}{l}\text { Ayaz et al. } \\
(2012)\end{array}$ \\
\hline Vertical flow constructed wetland & $\begin{array}{l}\text { Intermittent aeration }+ \text { step } \\
\text { feeding }\end{array}$ & $\begin{array}{l}96 \% \text { for } \mathrm{NH}_{4}^{+}-\mathrm{N} \\
82 \% \text { for } \mathrm{TN}\end{array}$ & $\begin{array}{l}\text { Alternate aerobic and anaerobic regions were } \\
\text { created effectively with intermittent aeration. } \\
\text { Intermittent aeration combined with step-feeding } \\
\text { strategy (reactor E) significantly improved the } \\
\text { removal of organics, ammonium nitrogen }\left(\mathrm{NH}_{4}^{+}-\mathrm{N}\right) \text {, } \\
\text { and total nitrogen (TN) simultaneously }\end{array}$ & $\begin{array}{l}\text { Fan et al. } \\
\text { (2013a) }\end{array}$ \\
\hline $\begin{array}{l}\text { Four-stage vertical flow } \\
\text { constructed wetland }\end{array}$ & Tidal flow + step-feeding & $\begin{array}{l}96 \% \text { for } \mathrm{NH}_{4}^{+}-\mathrm{N} \\
83 \% \text { for } \mathrm{TN}\end{array}$ & $\begin{array}{l}\text { The authors linked such enhanced performances to } \\
\text { the bed resting time (which provides better } \\
\text { aeration for nitrification) and up-flow stage/delayed } \\
\text { input of side stream(s) (which ensures the favorable } \\
\text { environment for better denitrification) }\end{array}$ & $\begin{array}{l}\text { Hu et al. } \\
\text { (2012b) }\end{array}$ \\
\hline $\begin{array}{r}\text { Baffled subsurface-flow } \\
\text { constructed wetland }\end{array}$ & $\begin{array}{l}\text { Organic rice husk as wetland } \\
\text { matrix }\end{array}$ & $\begin{array}{l}74 \%, 84 \%, \text { and } 99 \% \text { at } \\
\text { HRT of } 2,3 \text {, and } 5 \text { days, near } \\
\text { complete TON removal }\end{array}$ & $\begin{array}{l}\text { Rice husks as wetland media provided the COD as } \\
\text { the electron donor in the denitrification process; a } \\
\text { longer pathway allows more contact of the } \\
\text { wastewater with the rhizomes and micro-aerobic } \\
\text { stages }\end{array}$ & $\begin{array}{l}\text { Tee et al. } \\
(2012)\end{array}$ \\
\hline $\begin{array}{l}\text { Integrated constructed wetland } \\
\text { system (CWS) }\end{array}$ & $\begin{array}{l}\text { Up-flow VFCW + floating } \\
\text { bed + sand filter tank }\end{array}$ & $\begin{array}{l}98.05 \% \text { for } \mathrm{NH}_{4}^{+}-\mathrm{N} \\
92.41 \% \text { for } \mathrm{TN}\end{array}$ & $\begin{array}{l}\text { The integrated CWS was designed to reduce } \\
\text { nitrogen from secondary effluent. Carbon resource } \\
\text { was a key to optimal denitrification. Peat was used } \\
\text { as } \mathrm{C} \text { source for denitrifying bacteria that can remove } \\
\mathrm{NO}_{3}^{-}-\mathrm{N} \text {, as well as } \mathrm{NH}_{4}^{+}-\mathrm{N}\end{array}$ & $\begin{array}{l}\text { Xiong } \\
\text { et al. } \\
(2011)\end{array}$ \\
\hline $\begin{array}{l}\text { Pilot-scale hybrid constructed } \\
\text { wetland system }\end{array}$ & $\begin{array}{l}\text { VFCW + HFCW + VFCW } \\
\text { Coco-peat as bed media }\end{array}$ & $\begin{array}{l}86 \% \text { for } \mathrm{NH}_{4}^{+}-\mathrm{N} \\
50 \% \text { for } \mathrm{NO}_{3}^{-} \mathrm{N}\end{array}$ & $\begin{array}{l}\text { Simultaneous nitrification and denitrification were } \\
\text { attributed to the unique characteristics of the coco- } \\
\text { peat media, which allowed greater atmospheric } \\
\text { oxygen transfer for nitrification and supply of } \\
\text { organic carbon for denitrification }\end{array}$ & $\begin{array}{l}\text { Saeed } \\
\text { et al. } \\
(2012)\end{array}$ \\
\hline
\end{tabular}

carbon source (Section 2.2), and the calculated $\mathrm{C} / \mathrm{N}$ ratios (COD/ $\mathrm{NO}_{3}^{-}-\mathrm{N}$ ) in the stage 2 of HSFCW1 and HSFCW3 averaged 4.6 and 5.3 (Fig. S1), respectively, slightly higher than the stoichiometric value of 3.75 required for denitrification. However, this ratio may still be inefficient because the actual required $\mathrm{C} / \mathrm{N}$ ratio for complete denitrification could be multifold compared with the theoretical ratio (Her and Huang, 1995).

Compared with $55.5 \%$ and $56.4 \%$ of TN removal rates in HSFCW1 and HSFCW3, respectively, 60.6\% TN removal was achieved in HSFCW2 using step-feeding strategy. Thus, the effectiveness of step-feeding in promoting TN removal was demonstrated and could be attributed to carbon availability for denitrification as introduced by step-feeding. $\mathrm{C} / \mathrm{N}$ ratio was found to be as high as 13.9 in the anoxic stage of HSFCW2 (Fig. S1). However, since DO in the anoxic stage was not "anoxic" enough (Fig. 2) and excess oxygen suppressed the enzyme system required for denitrification, the treatment capacity of HSFCW2 with step-feeding could not be improved further owing to relatively high DO content in the anoxic stage. Notably, the best performance of TN removal was achieved in HSFCW4 (Table 1 and Fig. 3d), the TN removal efficiency in HSFCW4 (88.1\%) was significantly higher than that of the other HSFCWs (Table S1). Given that $\mathrm{NH}_{4}^{+}-\mathrm{N}$ removal was satisfactorily guaranteed in all HSFCWs in this study, the high TN removal rate in HSFCW4 could be ascribed to two aspects: (1) low DO content was obtained in anoxic stage after the buffering stage, favoring denitrification, and thus, the nitrified products derived from the previous aerated stages could be denitrified in the anoxic environment of HSFCW4 (Ding et al., 2012; Fan et al., 2013b); and (2) stepfeeding played a major role in boosting TN removal efficiency by introducing carbon and filling the gap to denitrify the nitrified nitrogen produced in the previous stages (the calculated value of the $\mathrm{C} / \mathrm{N}$ ratio averaged 14.3 (Fig. S1)), thereby overcoming the carbon deficiency problem that often restricts reactions from classical microbiological nitrogen removal in constructed wetlands ( $\mathrm{Hu}$ et al., 2012b; Lu et al., 2009; Saeed and Sun, 2012).

To achieve high nitrogen removal, appropriate oxygen environment and proper carbon source addition are necessary (Table 3 ). Hybrid (integrated) constructed wetlands (Ayaz et al., 2012; Saeed et al., 2012; Xiong et al., 2011), intermittent aeration (Fan et al., 2013a), and tide flow (Hu et al., 2012b) have been used to create alternating oxygen distribution for nitrification and denitrification. Meanwhile, recirculation (Ayaz et al., 2012), step-feeding (Fan et al., 2013a; Hu et al., 2012b), and organic wetland matrix (Saeed et al., 2012; Tee et al., 2012; Xiong et al., 2011) could provide essential carbon source for the denitrification process. In this study, the five-stage horizontal subsurface flow constructed wetland (HSFCW4) was integrated with artificial aeration, anoxic treatment, and step-feeding strategies. The experimental results showed that high TN removal efficiency, above $88 \%$, could be achieved under DO control and certain influent flow distribution 
ratio without recirculation or the addition of internal/external carbon source, which was comparable to the results of other studies.

\subsection{Microbial abundance and activities}

The abundance, biodiversity, and activity of microbes, which play a significant role in the proper functioning and maintenance of the wetland system, are mainly dependent on environmental parameters (i.e., $\mathrm{pH}, \mathrm{DO}$, redox potential, and temperature), wastewater properties (i.e., nutrient quality and availability, and toxicant), filter material or soil type, plants, and operating conditions (i.e., loading, feed mode, and retention time). When one or two factors are altered, the abundance, biodiversity, and activity of microbes will change accordingly (Kadlec and Wallace, 2008; Truu et al., 2009). In this study, the microbial abundance and activity elucidated great diversity at different stages in various wetland systems because of different DO control strategies (artificial aeration and sealing anoxic treatment) and influent distribution strategies (with or without step-feeding) (Fig. 4a and b).

Despite various wetland systems, with few exceptions, microbial abundance (Fig. 4a) and microbial activities (Fig. 4b) in the first aerobic stages were substantially higher than those in the other stages $(p<0.05)$, demonstrating that the microbial community was stimulated by favorable aerobic conditions and nutrient availability. These results are consistent with the findings of Hu et al. (2012b) that the respiration rates of heterotrophic biomass and ammonia oxidation bacteria (AOB) in stage 1 (first chamber of a four-stage constructed wetland) were substantially higher than those in the other stages by measuring the diversity of the microbial activities along the stages. Low DO induced from sealing anoxic treatment and poor carbon source availability resulted in lower microbial abundance and microbial activity for the second
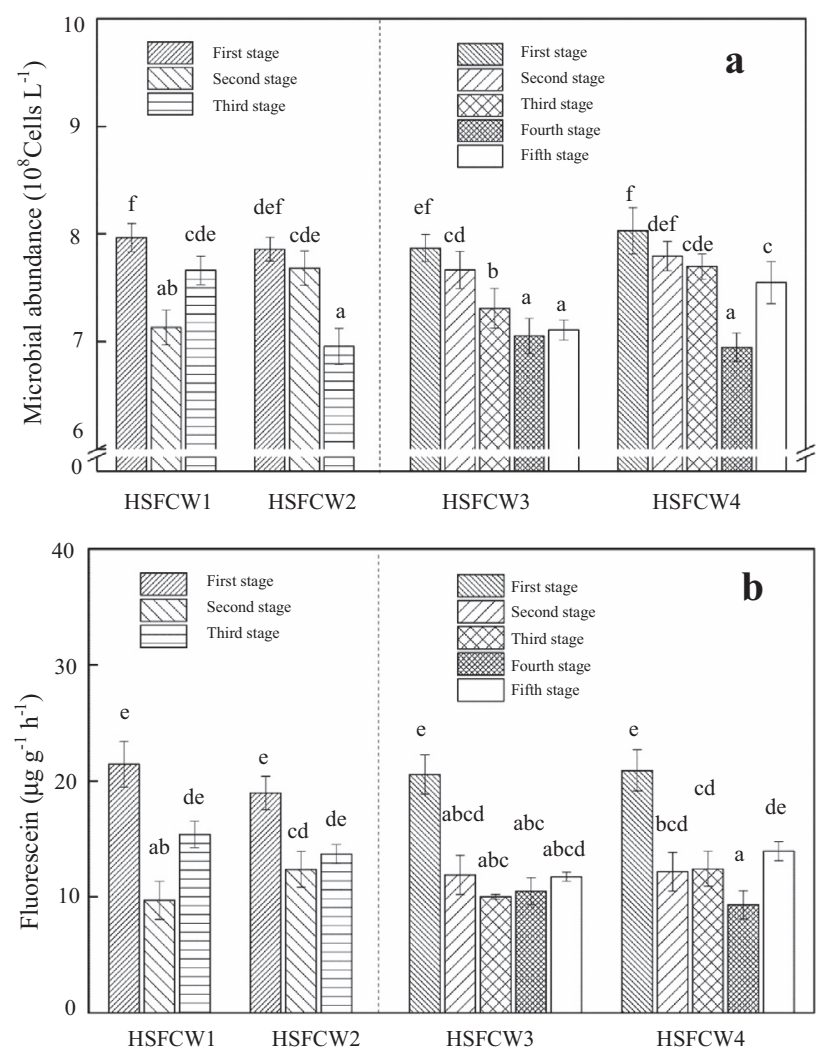

Fig. 4. Abundance and activity of microbes in different HSFCWs: (a) abundance and (b) activity. The different letters indicate significant difference, which was analyzed by Tukey HSD's multiple range test $(P=0.05)$. stage in HSFCW1 and the third and fourth stages in HSFCW3 and HSFCW4. Microbial abundance in the second stage of HSFCW2 with step-feeding was significantly higher than that of HSFCW1 without step-feeding $(p<0.05)$, and the same phenomenon occurred when compared with microbial abundance in the third stage between HSFCW3 and HSFCW4 (Fig. 5a). Microbial activities represented the same pattern between HSFCWs with step-feeding and the corresponding HSFCWs without step-feeding (Fig. 5b), although the difference two systems was insignificant $(p>0.05)$. A probable explanation could be the enhanced denitrifying process, which was stimulated in the favorable anoxic condition and supported by the carbon supply from step-feeding. Compared with HSFCW3, the excess part of microbial abundance in the third stage in HSFCW4 was believed to consist of denitrifiers, as extremely low DO was maintained in HSFCW4 (Fig. 2a). TN removal increased to approximately $8 \%$ from $3-1$ to $4-1$ (Fig. 4 d), which indicated the effectiveness of step-feeding to improve the microbial population as well as enhance TN removal (Fan et al., 2013a).

One limitation of this study was the lack of any plants in changing the microbial abundance and activities in the HSFCWs. The potential effects of wetland plants include enhancement of oxygen availability, release of organic compounds (such as sugars and organic acids) into filter matrix to stimulate microbial activities, and direct uptake of pollutants by plants. Although plants do not contribute "extra" oxygen to any appreciable degree to facilitate organics and nutrients removal (Kadlec and Wallace, 2008; Kuschk et al., 2003), which is the reason why artificial aeration was employed in this study and many other studies; the presence of plant was reported to increase the enzyme activities and thus improve the efficiency of wastewater treatment (Wang et al., 2013; Zhang et al., 2010). Besides, in another study by Zhang et al. (2011), they found that both plant types (monocot and dicot) and species richness have a profound effect on removal of COD, $\mathrm{NH}_{4}^{+}-\mathrm{N}$ and $\mathrm{NO}_{3}^{-}-\mathrm{N}$. As COD and $\mathrm{NH}_{4}^{+}-\mathrm{N}$ removal have already been guaranteed by sufficient DO supplied by artificial aeration (Table 1 ), if plants are involved in the present HSFCWs, they are more likely to enhance $\mathrm{NO}_{3}^{-}-\mathrm{N}$ by stimulating denitrifier and enzymes that involved in denitrification process, which deserves further study.

\section{Conclusion}

Nitrification was greatly enhanced by high DO concentration due to artificial aeration, resulting in nearly complete $\mathrm{NH}_{4}^{+}-\mathrm{N}$ removal for all HSFCWs. Sufficient carbon source introduced from step-feeding greatly improved denitrification when an effective anoxic condition was created. With the best scheme HSFCW4, average TN removal of $88.1 \%$ could be achieved, significantly higher than $55.5 \%, 60.6 \%$, and $56.4 \%$ for HSFCWs $1-3(p<0.01)$, respectively. The results provided significant evidence on artificial aeration and artificial anoxic treatment, and step-feeding strategy is feasible for HSFCWs to achieve high nitrogen removal.

\section{Acknowledgements}

This study was supported by the Major Science and Technology Program for Water Pollution Control and Treatment (No. 2012ZX07203004), Program for New Century Excellent Talents in University (No. NCET-11-0468), and the Public Science and Technology Research Funds Projects of Ocean (No. 201305003).

\section{Appendix A. Supplementary data}

Supplementary data associated with this article can be found, in the online version, at http://dx.doi.org/10.1016/j.biortech.2014. 07.004. 


\section{References}

Ayaz, S.Ç., Aktas, Ö., Findık, N., Akça, L., Kınacı, C., 2012. Effect of recirculation on nitrogen removal in a hybrid constructed wetland system. Ecol. Eng. 40, 1-5.

Brix, H., 1994. Use of constructed wetlands in water pollution control, historical development, present status, and future perspectives. Water Sci. Technol. 30, 209-224.

Conley, D.J., Paerl, H.W., Howarth, R.W., Boesch, D.F., Seitzinger, S.P., Havens, K.E., et al., 2009. Controlling eutrophication, nitrogen and phosphorus. Science 323, 1014-1015.

Ding, Y., Song, X., Wang, Y., Yan, D., 2012. Effects of dissolved oxygen and influent $\mathrm{COD} / \mathrm{N}$ ratios on nitrogen removal in horizontal subsurface flow constructed wetland. Ecol. Eng. 46, 107-111.

Fan, J., Liang, S., Zhang, B., Zhang, J., 2013a. Enhanced organics and nitrogen removal in batch-operated vertical flow constructed wetlands by combination of intermittent aeration and step feeding strategy. Environ. Sci. Pollut. Res., 1-8.

Fan, J., Zhang, B., Zhang, J., Ngo, H.H., Guo, W., Liu, F., et al., 2013b. Intermittent aeration strategy to enhance organics and nitrogen removal in subsurface flow constructed wetlands. Bioresour. Technol. 141, 117-122.

Green, V., Stott, D., Diack, M., 2006. Assay for fluorescein diacetate hydrolytic activity, optimization for soil samples. Soil Biol. Biochem. 38, 693-701.

Her, J.J., Huang, J.S., 1995. Influences of carbon source and C/N ratio on nitrate/ nitrite denitrification and carbon breakthrough. Bioresour. Technol. 54, 45-51.

Hu, Y., Zhao, Y., Zhao, X., Kumar, J.L., 2012a. High rate nitrogen removal in an alum sludge-based intermittent aeration constructed wetland. Environ. Sci. Technol. 46, 4583-4590.

Hu, Y.S., Zhao, Y.Q., Zhao, X.H., Kumar, J.L., 2012b. Comprehensive analysis of stepfeeding strategy to enhance biological nitrogen removal in alum sludge-based tidal flow constructed wetlands. Bioresour. Technol. 111, 27-35.

Judd, S., 2008. The status of membrane bioreactor technology. Trends Biotechnol. 26, 109-116.

Kadlec, R.H., Wallace, S., 2008. Treatment Wetlands. CRC Press, Boca Raton, FL, USA.

Kuschk, P., Wiessner, A., Kappelmeyer, U., Weißbrodt, E., Kästner, M., Stottmeister, U., 2003. Annual cycle of nitrogen removal by a pilot-scale subsurface horizontal flow in a constructed wetland under moderate climate. Water Res. 37, 4236-4242.

Li, F.M., Lu, L., Zheng, X., Zhang, X.W., 2014. Three-stage horizontal subsurface flow constructed wetlands for organics and nitrogen removal: effect of aeration. Ecol. Eng. 68, 90-96.

Lu, S., Hu, H., Sun, Y., Yang, J., 2009. Effect of carbon source on the denitrification in constructed wetlands. J. Environ. Sci. 21, 1036-1043 (China).

Ouellet-Plamondon, C., Chazarenc, F., Comeau, Y., Brisson, J., 2006. Artificial aeration to increase pollutant removal efficiency of constructed wetlands in cold climate. Ecol. Eng. 27, 258-264.

Porter, K.G., 1980. The use of DAPI for identifying and counting aquatic microflora. Limnol. Oceanogr. 25, 943-948.

Saeed, T., Afrin, R., Muyeed, A.A., Sun, G., 2012. Treatment of tannery wastewater in a pilot-scale hybrid constructed wetland system in Bangladesh. Chemosphere 88, 1065-1073.
Saeed, T., Sun, G., 2012. A review on nitrogen and organics removal mechanisms in subsurface flow constructed wetlands, dependency on environmental parameters, operating conditions and supporting media. J. Environ. Manage. $112,429-448$.

SEPA (State Environment Protection Administration), 2007. Directory of environmental quality standards for water. Available from: http:// www.zhb.gov.cn/tech/hjbz/ (accessed 07.11.11) (in Chinese).

Standard Method for the Examination of Water and Waste water Editorial Board, 2002. Standard method for the examination of water and waste water, fourth ed. Environmental Science Press of China, Beijing, China.

Stare, A., Vrečko, D., Hvala, N., Strmčnik, S., 2007. Comparison of control strategies for nitrogen removal in an activated sludge process in terms of operating costs, a simulation study. Water Res. 41, 2004-2014.

Stefanakis, A.I., Akratos, C.S., Tsihrintzis, V.A., 2011. Effect of wastewater stepfeeding on removal efficiency of pilot-scale horizontal subsurface flow constructed wetlands. Ecol. Eng. 37, 431-443.

Sun, G., Zhao, Y., Allen, S., 2005. Enhanced removal of organic matter and ammoniacal-nitrogen in a column experiment of tidal flow constructed wetland system. J. Biotechnol. 115, 189-197.

Tanner, C., Kadlec, R., 2003. Oxygen flux implications of observed nitrogen removal rates in subsurface-flow treatment wetlands. Water Sci. Technol. 48, 191-198.

Tee, H.C., Lim, P.E., Seng, C.E., Nawi, M.A.M., 2012. Newly developed baffled subsurface-flow constructed wetland for the enhancement of nitrogen removal. Bioresour. Technol. 104, 235-242.

Thauer, R.K., Jungermann, K., Decker, K., 1977. Energy conservation in chemotrophic anaerobic bacteria. Bacteriol. Rev. 41, 100.

Truu, M., Juhanson, J., Truu, J., 2009. Microbial biomass, activity and community composition in constructed wetlands. Sci. Total Environ. 407, 3958-3971.

Vymazal, J., 2011. Constructed wetlands for wastewater treatment five decades of experience. Environ. Sci. Technol. 45, 61-69.

Vymazal, J., Kropfelova, L., 2009. Removal of organics in constructed wetlands with horizontal sub-surface flow, a review of the field experience. Sci. Total Environ. 407, 3911-3922.

Wang, H., Chen, Z.X., Zhang, X.Y., Zhu, S.X., Ge, Y., Chang, S.X., Zhang, C.B., Huang, C.C., Chang, J., 2013. Plant species richness increased belowground plant biomass and substrate nitrogen removal in a constructed wetland. Clean Soil Air Water 41, 657-664.

Warneke, S., Schipper, L.A., Matiasek, M.G., Scow, K.M., Cameron, S., Bruesewitz, D.A., et al., 2011. Nitrate removal, communities of denitrifiers and adverse effects in different carbon substrates for use in denitrification beds. Water Res. $45,5463-5475$.

Xiong, J., Guo, G., Mahmood, Q., Yue, M., 2011. Nitrogen removal from secondary effluent by using integrated constructed wetland system. Ecol. Eng. 37, 659-662.

Zhang, C.B., Liu, W.L., Wang, J., Ge, Y., Ge, Y., Chang, S.X., Chang, J., 2011. Effects of monocot and dicot types and species richness in mesocosm constructed wetlands on removal of pollutants from wastewater. Bioresour. Technol. 102 $10260-10265$.

Zhang, C.B., Wang, J., Liu, W.L., Zhu, S.X., Liu, D., Chang, S.X., Chang, J., Ge, Y., 2010 Effects of plant diversity on nutrient retention and enzyme activities in a fullscale constructed wetland. Bioresour. Technol. 101, 1686-1692. 